\title{
Comprehensive assessment of groundwater quality using heavy metal pollution indices and geospatial technique: A case study from Wanaparthy watershed of upper Krishna River basin, Telangana, India.
}

\section{Suantak Paolalsiam Vaiphei}

National Geophysical Research Institute CSIR

Rama Mohan Kurakalva ( $\square$ krenviron@ngri.res.in )

National Geophysical Research Institute CSIR https://orcid.org/0000-0001-7199-7475

\section{Research Article}

Keywords: Heavy metal pollution indices, Spatial variations, Groundwater, Krishna River basin, Wanaparthy

Posted Date: June 21st, 2021

DOI: https://doi.org/10.21203/rs.3.rs-591235/v1

License: @ (i) This work is licensed under a Creative Commons Attribution 4.0 International License. Read Full License 


\section{Abstract}

The present study is to characterize groundwater quality using heavy metal pollution indices and geospatial variations. A total of 58 samples from hand pump/submersible bore wells were collected from the Wanaparthy watershed of the upper Krishna River basin according to the grid size (5*6 km 2 ). The heavy metals concentration in groundwater samples are found in the order of $\mathrm{Zn}(38.67 \%)>\mathrm{B}(32.67 \%)>\mathrm{Ba}(13.59 \%)>$ $\operatorname{As}(8.49 \%)>\mathrm{Hg}(3.71 \%)>\mathrm{Cr}(1.28 \%)>\mathrm{Ni}(0.52 \%)>\mathrm{Cd}(0.47 \%)$. Among these heavy metals, arsenic $(22.4 \%)$ and mercury (5.1\%) were found above the permissible limits of WHO drinking water guideline values. A positive correlation between $\mathrm{pH}$ versus $\mathrm{B} / \mathrm{Ba} / \mathrm{Hg}$, TH versus EC/TDS, and $\mathrm{B}$ versus $\mathrm{Ba}$ indicates the presence of metals due to chemical reaction (rock-water interaction). Arsenic correlation with EC/TDS/TH indicates artificial intervention. Drainage network analysis enumerates high concentration of parameters at near or joining to upper order of drainage system, which might be due to input of runoff water (interaction of variable rocks composition) and later stage infiltration to subsurface and reached to an aquifer. Heavy metal pollution index (HPI) showed $86.2 \%$ of samples are in the category of low class, whereas $12.1 \%$ of samples fall within medium class. According to metal index (MI) classification, $12.1 \%$ samples are in very pure, $24.14 \%$ samples are pure, while the remaining $63.8 \%$ samples are in the slightly to strongly affect category. This study suggested the main source of heavy metals in groundwater might be from the dominant granitoid rocks because the area is mostly devoid of industrialization.

\section{Introduction}

Renewable groundwater is found between layers of impermeable rock formations known as an aquifer. Aquifers are connected through joint, crack, fracture, or structurally deformed zone. It is essential to know the portability of groundwater and the amount of recharge and discharge ratio because the future generation depends on how we utilized and managed the aquifer system. In most parts of India, highly dependent on groundwater for drinking purposes, which gives rise to risk due to limited resources of surface water and a highly dense population. Heavy metals in groundwater are generally at low concentrations in the undisturbed environment due to natural chemical weathering and rock-water interaction (Tiwari et al., 2016; Karbassi et al., 2007). Groundwater pollution is not only influence water quality but also render chaos to a health problem, economic growth, and social life (Singh and Kamal 2017; Marcovecchio et al. 2007). Heavy metal concentrations in groundwater are very much concerned about the environmental pollution and wellbeing of humans. This is because of heavy metals are non-degradable and once it reaches into body system it accumulates and causes diseases at very low content, they are highly dangerous (Zakhem et al. 2015; Vinodhini and Narayanan 2008; Lohani et al. 2008; Marcovecchio et al. .2007; Momodu and Aayako 2010; Lee et al. 2007). Generally, heavy/ trace metals can be defined as a group of elements with an atomic density above $4000 \mathrm{~kg} / \mathrm{m}^{3}$ (Garbarino et al. 1995; Hutton and Symon 1986). Heavy metals in groundwater can be either from natural or anthropogenic processes; whereas natural processes include weathering, chemical reactions of elements, soil leaching, etc. while anthropogenic are from domestic waste, fertilizers, urbanization, mining, industrial waste, etc. (Agarwal et al. 2013; Zarazua et al. 2006, Reiners et al. 1975). Among the heavy metals, a few of them like Ni, Cr, and Zn are essential as micronutrients for biochemical activities in aquatic life though they become highly toxic in higher concentrations (Kumar et al., 2012; Nurnberg 1982). Arsenic is considered highly hazardous due to its toxic and carcinogenic to human health even at low concentrations (Selvam et al. 2015), and the mineral source is arsenopyrite (FeAsS). Other heavy metals $\mathrm{B}, \mathrm{Ba}, \mathrm{Be}$, and $\mathrm{Hg}$ are known to less health importance, but still, their 
presence in groundwater is considered toxic at low concentration. A review of the literature showed that many researchers had reported the groundwater quality assessment using heavy metal pollution index (HPI) and metal index (MI) to find out the additive result of heavy/trace metals in water for quick analyses of overall groundwater standard for drinking and effect on human health (Abbas et al. 2021; Wu et al. 2021; Panseriya et al.2020; Singh and Kamal 2017; Tiwari et al. 2015; Zakhem and Hafez 2015; Goher et al. 2014; Protano et al. 2014; Yankey et al. 2013; Prasanna et al. 2012; Giri et al. 2010; Kikuchi et al. .2009; Zhang et al. .2009; Pandey et al. 2009; Prasad and Sangita 2008). This study is the continuation of an earlier investigation of major ions, hydrogeochemical process seasonal variation, and health risk assessment of groundwater (Vaiphei and Kurakalva, 2021; Vaiphei et al. 2020) in the Wanaparthy watershed. Since no report has been found on groundwater studies on heavy metals contamination in Wanaparthy watershed, Telangana, India, hence the present study has a major objective on understanding the groundwater quality with respect to heavy metals concentration and distribution. The methods to be followed are identifying individual heavy metal concentration, heavy metal pollution index (HPI), metal index (MI), and their spatial distribution in the study area.

\section{Study Area}

Wanaparthy watershed is located in the upper Krishna River basin between $16^{\circ} 19^{\prime} 1$ " to $16^{\circ} 49^{\prime} 53^{\prime \prime} \mathrm{N}$ latitude and $77^{\circ} 49^{\prime} 21^{\prime \prime}$ to $78^{\circ} 12^{\prime} 55^{\prime \prime} \mathrm{E}$ longitude of Telangana state in southern India (Fig. 1a), covering an area of $1600 \mathrm{~km}^{2}$. The geomorphology of the area, North-west, and north-eastern region have higher topography, which gradually slopes down towards the south-west side (Fig .1b); the elevation ranges from 309-692m (AMSL) (ESM_Fig. 1). The dominant river system in the area is of dendritic pattern where the higher-order streams finally reach to major Krishna River. Krishna river originates from Western Ghats (Maharashtra) and passes through the southern part of Telangana, which reaches into the Bay of Bengal on the eastern coast (Andhra Pradesh). Krishna river serves as a significant water source for drinking, domestic purposes, and agriculture in the study area. Red soils, lateritic soils, and black cotton soils are the main dominant soil types. The major cultivation in the study is rice, maize, sugarcane, bajra, cotton, mango, grape, lemon, papaya, pomegranate, etc., whereas there is less predominant of mining and industries. The area comes under a tropical semi-arid climate with temperature ranging from between $16.9^{\circ} \mathrm{C}$ to $42^{\circ} \mathrm{C}$. The dominant rock formation of the study area belongs to the peninsular gneissic complex and Dharwar group of Precambrian age consisting of grey biotite granite, migmatite, leucogranite, alkali feldspar granite, pink biotite granite, banded migmatite quartzite, amphibolite, etc. There is migmatite intrusion which cut across the massive peninsular gneissic complex in the north-west to north-east direction Fig. 2 (GSI).

\section{Materials And Methods}

Fifty-eight water samples were collected from hand pump/submersible bore wells as per the grid $\left(5 * 6 \mathrm{~km}^{2}\right)$ drawn for the study area during March 2019 from the Wanaparthy watershed. Sampling points were fixed to collect the samples preferably either from the center of the village or center of the prepared grid size $\left(5^{\star} 6\right.$ $\mathrm{km}^{2}$ ). Sampling points were fixed to collect the samples preferably either from the center of the village or center of the prepared grid size $\left(5^{\star} 6 \mathrm{~km}^{2}\right)$. The groundwater samples were collected in high-density polyethylene (HDPE) bottles prewashed with $10 \%$ nitric acid followed by rinsing with double distilled water. Before collecting the samples, water is drawn out from the hand pump, or submersible bore wells for about 10 minutes to 
confiscate out the stagnant water. Two sets of samples were collected separately in 500ml and 60ml HDPE bottles. The $500 \mathrm{ml}$ water samples were utilized for titrimetric measurement of total hardness using EDTA (ethylenediamine tetraacetic acid), ammonium chloride-ammonia buffer, Eriochrome Black-T (EBT), while the total alkalinity was measured using sulphuric acid, phenolphthalein indicator, and methyl orange following APHA (2005) standard procedure. The $60 \mathrm{ml}$ containers were acidified with 2-3ml of conc. $\mathrm{HNO}_{3}$ to keep dissolved and to stabilize the heavy metals (Kumar et al. 2012). Water quality parameters like pH, TDS, and EC were measured in-situ using portable meters (Hanna, HI98130). Later, samples were transported to the Environmental Geochemistry Lab of CSIR-NGRI, Hyderabad. Heavy metals (As, Ba, Cd, Cr, Hg, Ni, and Zn) concentrations in groundwater were analyzed using ICP-OES (Optima 4300 DV, Perkin Elmer). A calibration curve is constructed using freshly prepared working standards and continued testing until the correlation coefficient $\left(r^{2}\right)$ close to 1 .

\subsection{Heavy metal pollution index ( $\mathrm{HPI}) \mathrm{Zn}, \mathrm{Ba}, \mathrm{As}, \mathrm{Hg}, \mathrm{Cr}, \mathrm{Ni}, \mathrm{Cd}$ )}

$\mathrm{HPI}$ is a rating method of water quality utilizing determining individual heavy metal concentrations and their composite effects (Zakhem and Hafez 2015 and Sheykhi and Moore 2012). The rating or weights $\left(W_{i}\right)$ is assigned between 0 and 1 for each heavy metal, which is based on the importance of individual quality considerations or by taking the inverse proportional value of approved standard to all metals considered (Mohan et al. 1996; Horton 1965). According to Tiwari et al. (2015) and Prasad and Bose (2001), different researchers/scholars set their limit values for HPI, and the critical limit value of HPI for drinking water is 100 . Edet and Offiong (2002) categorized HPI into three distinct classes; low (HPI<15), medium ), and high (HPI>30). However, this study followed the classification of HPI based on the description of Kumar et al. (2012). These were explained as low $(\mathrm{HPI}<19)$, medium , and high $(\mathrm{HPI}>38)$. The concentration limits (i.e., the maximum permissible value $S_{i}$ and maximum desirable value $I_{i}$ for every parameter) are based on the international standard (WHO 2011). Maximum permissible value $S_{i}$ can be defined as beyond this limit it is not advisable to drinking water while maximum desirable value $I_{i}$ is one way of relaxation limit set by the individual organization

where it gives the best water to drink purpose (like every country will have different maximum desirable value $I_{i}$ it depends on the economy of the state). The HPI is calculated using the following equations below (Mohan et al.,1996). 
$\mathrm{HPI}=\frac{\sum_{i=1}^{n} W_{i} Q_{i}}{\sum_{i=1}^{n} W_{i}} \quad$ eq. 1

where,

$Q_{i}$ is the sub-index of $i^{\text {th }}$ parameter

$W_{i}$ is the unit weight of $i^{\text {th }}$ parameter, and $\mathrm{n}$ is the number of parameters used

The unit weight $\left(W_{i}\right)$ is obtained by using the formula

$W_{i}=K / S_{i}$

where $K$ is proportional constant (1) and $S_{i}$ is the standard permissible value of $i^{\text {th }}$ parameter

The sub-index $\left(Q_{i}\right)$ of the parameter is given by

$Q_{i}=\sum_{i=1}^{n} \frac{\left|M_{i}(-) I_{i}\right|}{s_{i}-I_{i}} * 100 \quad$ eq. 2

where,

$M_{i}$ is the monitor value of the metal in $i^{\text {th }}$ parameter

$I_{i}$ is the ideal value of the metal in $i^{\text {th }}$ parameter

$S_{i}$ is the standard value of the metal in $i^{\text {th }}$ parameter and

$(-)$ sign is to have the absolute value of the two numbers

\subsection{Metal Index}

$\mathrm{Ml}$ is also an important factor in determining groundwater quality for public concern. Metal Index is classified as follows; very pure $(\mathrm{Ml}<0.3)$, pure, slightly affected, moderately affected, strongly affected and seriously affected $(\mathrm{MI} \geq 6$ ). MI value is considered a sign of warning when it is greater than 1 (Goher et al., 2014; Bakan et al., 2010). Metal Index (Tamasi and Cini 2004) is calculated as:

$$
M I=\sum\left[C_{i} /(M A C)_{i}\right] \quad \text { eq. } 3
$$

where $C_{i}$ is the measure concentration of each metal, $M A C$ is the maximum permissible limit

\section{system (GIS) analysis}

\subsection{Geographical information}

Geographical information system (GIS) helps in collecting and manipulation of a diverse range of spatial data and generates the spatial distribution phenomena of all individual values (Gupta and Srivastava 2010). GIS manipulates all water quality parameters, gives an overall idea, provides easy understanding to the people and policymakers (Singh et al. 2013). The inverse distance weighted interpolation method of ArcGIS- 10.7 software (GIS Lab, CSIR-NGRI, Hyderabad, India) was used to generate a spatial distribution map of all parameters.

\section{Results And Discussion}

\subsection{Physicochemical analysis}


Table. 1 describes the overall statistical arrangement of all water quality parameters investigated in the study area. All considered parameters permissible limits are following WHO (2011) standards. The spatial distribution maps of physicochemical parameters for temperature, pH, EC, TDS, TH, and TA were shown in ESM_Fig. 2 (a) to (f). Temperature and $\mathrm{pH}$ : The water temperature in the study ranged between $29^{\circ} \mathrm{C}-30^{\circ} \mathrm{C}$. Temperature is critical due to its tendency to cause a chemical reaction and control oxygen levels in the water. $\mathrm{pH}$ values obtained in this work are between 7.28 -8.43, which is between desirable limits of WHO (2011) drinking water guideline values. The value of $\mathrm{pH}$ in the study is not corrosive. $\mathrm{pH}$ has a positive correlation with $\mathrm{EC}$ and Alkalinity. For instance, $\mathrm{pH} 7$ is the neutral value of water. Suppose $\mathrm{pH}$ value is low than high corrosive properties and vice versa. Electrical conductivity (EC) values range from $640 \mu \mathrm{S} / \mathrm{cm}$ to $5890 \mu \mathrm{S} / \mathrm{cm}$, whereas $18.97 \%$ of samples are above the permissible limit of $1500 \mu \mathrm{S} / \mathrm{cm}$. Total dissolved solids (TDS) are found high in the area as most of the samples (81.03\%) are above the permissible limit of $1000 \mathrm{mg} / \mathrm{l}$.

Total Hardness (TH) ranges between $58.5-1480.5 \mathrm{mg} / \mathrm{l}$, where $46.55 \%$ of samples are beyond the permissible limit $(500 \mathrm{mg} / \mathrm{L})$ as prescribed by WHO. The average concentration of TH was found to be $526.57 \mathrm{mg} / \mathrm{L}$. Total Alkalinity (TA) is due to the contribution of carbonate $\left(\mathrm{CO}_{3}{ }^{2-}\right)$ and bicarbonate $\left(\mathrm{HCO}_{3}{ }^{-}\right)$ions in water and the main controlling factor. Alkalinity in the study area was found to be in the range of $60-580 \mathrm{mg} / \mathrm{l}$, which is within the permissible limit.

Heavy metals concentration in groundwater samples found descending order are as $\mathrm{Zn}(38.67 \%)>\mathrm{Ba}(13.59 \%)>\mathrm{As}(8.49 \%)>\mathrm{Hg}(3.71 \%)>\mathrm{Cr}(1.28 \%)>\mathrm{Ni}(0.52 \%)>\mathrm{Cd}(0.47 \%)$. $\mathrm{Zn}$ has the maximum concentration of all analyzed heavy metals in groundwater from the study area. According to the WHO limit, none of the samples found is above $3000 \mu \mathrm{g} / \mathrm{L}$ permissible. The concentration of $\mathrm{Zn}$ is within the limit, i.e., between 11.69-130.2 $\mathrm{g} / \mathrm{L}$, as shown in Fig.3(a). Though $\mathrm{Zn}$ is harmful in higher concentrations, it is also one of our essential heavy metals as they are consumed as organic compounds and salts in food, medicine, and drinking water. Zn gives good health through proper diet. Rusting of pipes that concentrate with water through the household tap is one major cause of high $\mathrm{Zn}$ in drinking water and affecting human health. Generally, zinc is associated with lead and cadmium in groundwater. Barium $(\mathrm{Ba})$ is in the third spot regarding the amount of percentage present in groundwater. It constitutes about $8.49 \%$ of the total content of metals. Though $\mathrm{Ba}$ is second, the concentration found is within the permissible limit, i.e., 0.033-26.71 $\mu \mathrm{g} / \mathrm{L}$ (Fig. 3b), where the maximum allowable is up to $700 \mu \mathrm{g} / \mathrm{L}$. Generally, Barium is high in regions where $\mathrm{pH}$ is low and associate with granite rocks, alkaline igneous rock, volcanic rocks, and sedimentary (Mn-rich) rocks. Arsenic (As) is a dangerous heavy metal because they are toxic even at trace concentration. It ranks fourth highest in order of composition in groundwater samples, contributing $8.49 \%$. Many samples $(22.41 \%)$ found to be is above the permissible limit of $10 \mu \mathrm{g} / \mathrm{L}$. The minimum and maximum range of As between 0.308-38.38 $\mu \mathrm{g} / \mathrm{L}$, as shown in Fig. 3(c). The natural source of arsenic is arsenopyrite (FeAsS); its association minerals are Fe and sulphide. Anthropogenic sources are chemical pesticides, industrial waste, coal burning, lead, and gold mining.

In contrast, mining and industrial activity in the study area are not prominent, so it imparts the idea of contamination through geogenic processes. Therefore, the chances of anthropogenic dominancy in the study area were found to be of using pesticides for agriculture activities. Mercury $(\mathrm{Hg})$ constitutes $3.71 \%$ of samples and is found in the range of $0.412-8.988 \mu \mathrm{g} / \mathrm{L}$ (Fig. 3d). The permissible limit of $\mathrm{Hg}$ is $6 \mu \mathrm{g} / \mathrm{L}$, where $3(5.17 \%)$ samples exceed the limit. Natural sources are volcanoes, hot springs, serpentinite changes to silica-carbonate in the presence of carbonate-rich water (Adolph, 1906 and White, 1957). At the same time, natural processes are 
hydroelectric plants, mine, paper industry wastes, etc. Chromium $(\mathrm{Cr})$ concentration is found between $0.123-$ $2.496 \mu \mathrm{g} / \mathrm{L}$, as shown in Fig. 3(e), and constitutes 1.28\%. No samples exceed the permissible limit 50 $\mathrm{gg} / \mathrm{L}$. Chromium in water is due to waste products from electroplating, leather tanning, and textile factories (Fetter 1993), while leaching of soils and rocks are the major sources. Nickel (Ni) concentration ranges from 0.012$0.865 \mu \mathrm{g} / \mathrm{L}$ (Fig. 3f), where no sample exceeds the permissible limit, i.e., $70 \mu \mathrm{g} / \mathrm{L}$. Generally, nickel is contaminating water bodies due to iron leaching. Sources of nickel are steel factories, non-ferrous alloys (aluminum, copper, zinc, tin, lead, brass, etc.), and superalloy (having high melting, less corrosion, strength, etc.). Cadmium (Cd) is a minor concentration among all heavy metals ranging from $0.277-0.544 \mu \mathrm{g} / \mathrm{L} \mathrm{(Fig.} 3 \mathrm{~g}$ ), constituting $0.47 \%$. None of the samples exceed the permissible limit $3 \mu \mathrm{g} / \mathrm{L}$. Cadmium is a trace metal present widely in nature (Xie et al. 2021) in crust and water. It is used for rusting resistance as well as to stabilized plastics. Cadmium is known for its uses in making batteries. Majorly environment contaminant medium is through water and air (release fossil fuels combustion). Cadmium is released to water from galvanized plumbing (coated with zinc), water pipes, domestic wastes, and fertilizer factories. Cadmium is generally associated with ores of zinc, copper, lead. When the groundwater is highly acidic, a chemical reaction occurs, resulting in a high $\mathrm{Cd}$ concentration in groundwater. Krishna et al. (2009) reported that heavy metals like $\mathrm{Ba}, \mathrm{Ni}$, $\mathrm{Cr}$ in water were controlled and associated by mixed origin from both natural and anthropogenic inputs, while, $\mathrm{As}, \mathrm{Zn}, \mathrm{Mn}, \mathrm{Fe}, \mathrm{Pb}$, and $\mathrm{Co}$ were due to anthropogenic sources. The study region also has similar lithology and peninsular region of South India, i.e., granitoid terrain of Medak district, Andhra Pradesh (presently under Telangana State, India).

\subsection{Pollution indices}

\subsubsection{Heavy metal pollution index (HPI)}

Seven heavy metals such as $\mathrm{Zn}, \mathrm{Ba}, \mathrm{As}, \mathrm{Hg}, \mathrm{Cr}, \mathrm{Ni}, \mathrm{Cd}$ were considered to determine the heavy metal pollution index of groundwater. Statistical calculation of HPI for heavy metals shown in Table 2 for groundwater samples. According to Kumar et al. (2012),three main classes are defined as low (HPI 19), medium , and high (HPI>38) were followed respectively, as shown in Table 3. From the HPI values, it is clear that 29 samples fall under the low category, which means less contamination, and it contributes $50 \%$ of the total area. $27(46.55 \%)$ samples fall within a medium group while only $2(3.45 \%)$ sample is found to have a high concentration of metals in the area. For a better understanding of heavy metals in the study, a scatter plot and spatial distribution map of HPI is generated, as shown in Fig. 4 and 5. Two samples (PRM-35 and 41) with high HPI values are found to be fall within the migmatite body, as shown in Fig.2, which suggests that migmatite rock might be the source of origin. Since the area is dominant with granitoid composition, it can play a vital role as a source of heavy metals in groundwater through natural processes because the study region is devoid of industrialization. This data will help the future investigation find the geochemical study of rocks and the extent of contamination in groundwater for better management.

\subsubsection{Metal Index (MI)}

The metal index is another way to check water quality by determining the concentration of heavy metals. Metal index help in classifying groundwater quality and is considered to be hazardous for drinking and aquatic life when Ml>1 (Goher et al., 2014). The metal index has grouped into six types based on their concentration such as very pure $(\mathrm{Ml}<0.3)$, pure , slightly affected, moderately affected, strongly affected and seriously affected 
(Ml $\geq 6)$ as shown in Table 4. Accordingly, it is found that 7(12.07\%) samples are in very pure category, $14(24.14 \%)$ samples are in pure category while the remaining $37(63.79 \%)$ samples contribute slightly affected to the strongly affected category. A spatial distribution map of the metal index is shown in Fig. 6 . Though one sample collected from Chegunta village falls within the seriously affected category of MI, it is clear that most of the groundwater in the area followed the trend to be affected. Therefore, it is the right time to take up control measurements so that groundwater can be saved and used in the long run.

\subsection{Correlation coefficient analysis}

The correlation coefficient index defines the relation of two variables which describe the sufficiently of a variable to relate to the other (Davis, 1986), such that high correlation coefficient values show good relation and vice versa. Determination of variables, i.e., the dependent $(x)$ is solely control by independent $(y)$ and vice versa (Voudouris et al., 2000). Also, if the correlation coefficient value is close to zero, then it does not correlate. A high positive value ( $r$ ) means a good relationship, but if it is negative, it is an inverse correlation. A statistical calculation was done to better understand the source of pollution, either anthropogenic or natural, according to Pearson's correlation matrix. The correlation coefficient of all parameters (physicochemical parameters and heavy metals) has shown in Table 5. Positive relation between $\mathrm{pH}$ with $\mathrm{Ba} / \mathrm{Hg}$; $\mathrm{TH}$ with EC/TDS shows the chemical reaction through the natural process; As with EC/TDS/TH indicates the source of chemical fertilizers from agricultural infiltration, domestic waste, and industrial discharge. While parameters that show negative or no relation indicates the source of heavy metals in groundwater is not an individual contribution of natural or anthropogenic sources.

\section{Conclusion}

This study integrated the heavy metals, physicochemical parameters, multivariant statistical methods, and ArcGIS to evaluate the groundwater quality and sources of pollution. Concentration of heavy metals related to abundance in groundwater samples are in order; $\mathrm{Zn}(38.67 \%)>\mathrm{Ba}(13.59 \%)>\mathrm{As}(8.49 \%)>\mathrm{Hg}(3.71 \%)>\mathrm{Cr}(1.28 \%)>$ $\mathrm{Ni}(0.52 \%)>\mathrm{Cd}(0.47 \%)$. Though $\mathrm{Zn}$ has the maximum concentration among all the heavy metals in the groundwater of the study area, none of the samples are above the permissible limit of $3000 \mu \mathrm{g} / \mathrm{L}$ (observed values are between 11.69-130.2 $\mu \mathrm{g} / \mathrm{L}$ ). Except for two heavy metals, namely As with $22.41 \%$ of samples and $\mathrm{Hg}$ with $5.17 \%$, samples are above WHO permissible limits for drinking water. According to HPI classification, most of the samples (86.21\%) fall under the low category of HPI (<19) revealed no significant health issue due to heavy metals. Correlation coefficient analyses suggest that the contribution of heavy metals in groundwater is due to natural (chemical reactions) and anthropogenic sources. From spatial distribution maps, HPI and MI have a higher concentration in small patches of the northeast side of Wanaparthy watershed. Considering the overall view of the spatial variation of the parameters investigated, a higher concentration of heavy metals is found near or joining to upper order drainage system. The higher concentrations of heavy metals might be due to the input of runoff water (interaction of variable rocks composition) from a higher elevation and later get infiltration (low lying/depression areas) to subsurface and reach the aquifer. Heavy metal pollution indices (HPI and $\mathrm{MI}$ ) suggested that the main source of heavy metals in groundwater might be from the dominant granitoid rocks because the area is mostly devoid of industrialization. The present work suggested the $\mathrm{Ml}$ value in $63.79 \%$ of the samples in Wanaparthy watershed is slightly affected to the strongly affected category, which means most groundwater samples need proper treatment before used for drinking purposes. 


\section{Declarations}

\section{Acknowledgments}

The authors are thankful to the Director, CSIR-NGRI, for permission to publish this research work. One of the authors Mr. Suantak Paolalsiam Vaiphei (SPV), acknowledges the financial support from the Council of Scientific and Industrial Research (CSIR), New Delhi. This work belongs to the part of Doctoral Research. The authors acknowledge the support rendered from the Environmental Geochemistry Lab and GIS Lab of CSIRNGRI for providing groundwater samples analysis and spatial analysis of data, respectively.

\section{References}

Abbas T, Akmal M, Aziz I, lqbal M, \& Ahmed H (2021) Risk assessment and GIS-based mapping of heavy metals in the secondary rock deposits derived soils of Islamabad, Pakistan. Environ Earth Sci, 80(3), 1-9. doi.org/10.1007/s12665-021-09397-w

Agarwal E, Agarwal R, Garg R D, Garg P K (2013) Delineation of groundwater potential zone: An AHP/ANP approach. Journal of earth system science, 122(3), 887-898.

APHA (2005) Standard methods for the examination of water and wastewater, 20th ed. American Public Health Association, Washington DC.

Babiker I S, Mohamed M A, Terao H, Kato K, Ohta K (2004) Assessment of groundwater contamination by nitrate leaching from intensive vegetable cultivation using geographical information system. Environment International, 29(8), 1009-1017. 10.1016/S0160-4120(03)00095-3

Bakan G, Ozkoç H B, Tulek S, Cuce H (2010) Integrated environmental quality assessment of Kızılırmak River and its coastal environment. Turkish Journal of Fisheries and Aquatic Sciences, 10(4), 453-462.

Davis J C (1986) Statistics and Data Analysis in Geology, 2nd ed. John Wiley \& Sons: New York.

Edet A E, Offiong O E (2002). Evaluation of water quality pollution indices for heavy metal contamination monitoring. A study case from Akpabuyo-Odukpani area, Lower Cross River Basin (southeastern Nigeria). GeoJournal, 57(4), 295-304.

Fetter CW (1993) Contaminant hydrogeology. Prentice Hall, Canada

Garbarino J R, Hayes H, Roth D, Antweider R, Brinton TI, Taylor H (1995) Contaminants in the Mississippi river. US geological survey circular, 1133.

Giri S, Singh G, Gupta S K, Jha VN, Tripathi RM (2010) An evaluation of metal contamination in surface and groundwater around a proposed uranium mining site, Jharkhand, India. Mine Water and the Environment, 29(3), 225-234. DOI 10.1007/s10230-010-0107-3

Goher ME, Hassan AM, Abdel-Moniem IA, Fahmy AH, El-sayed SM (2014) Evaluation of surface water quality and heavy metal indices of Ismailia Canal, Nile River, Egypt. The Egyptian Journal of Aquatic Research, 40(3), 225-233. doi.org/10.1016/j.ejar.2014.09.001 
Geologival Survey of India (GSI) http://bhukosh.gsi.gov.in/Bhukosh/Public

Gupta M, Srivastava P K (2010) Integrating GIS and remote sensing for identification of groundwater potential zones in the hilly terrain of Pavagarh, Gujarat, India. Water International, 35(2), 233-245. 43.

doi.org/10.1080/02508061003664419

Horton RK (1965) Index number system for rating water quality. Journal of Water Pollution Control Federation, $37(3), 300-306$.

Hutton, M., \& Symon, C. (1986). The quantities of cadmium, lead, mercury and arsenic entering the UK environment from human activities. Science of the total environment, 57, 129-150.

Karbassi A R, Nouri J, Ayaz G O (2007) Flocculation of trace metals during mixing of Talar river water with Caspian Seawater. Int J Environ Res 1(1):66-73.

Kikuchi T, Furuichi T, Hai H T, Tanaka S (2009) Assessment of heavy metal pollution in river water of Hanoi, Vietnam using multivariate analyses. Bulletin of environmental contamination and toxicology, 83(4), 575582.DOI 10.1007/s00128-009-9815-4

Krishna A K, Satyanarayanan M, Govil P K (2009) Assessment of heavy metal pollution in water using multivariate statistical techniques in an industrial area: a case study from Patancheru, Medak District, Andhra Pradesh, India. J. Hazard. Mater., 167(1-3), 366-373. doi.org/10.1016/j.jhazmat.2008.12.131

Kumar PS, Delson PD, Babu PT (2012) Appraisal of heavy metals in groundwater in Chennai city using a HPI model. Bulletin of environmental contamination and toxicology, 89(4), 793-798. DOI 10.1007/s00128-012-07945

Lee CS, Li XD, Zhang G, Li J, Ding AJ, Wang T (2007) Heavy metals and Pb isotopic composition of aerosols in urban and suburban areas of Hong Kong and Guangzhou, South China-evidence of the long-range transport of air contaminants. Atmospheric Environment, 41(2), 432-447. doi.org/10.1016/j.atmosenv.2006.07.035

Lohani M B, Singh A, Rupainwar D C, Dhar D N (2008) Seasonal variations of heavy metal contamination in river Gomti of Lucknow city region. Environmental Monitoring and assessment, 147(1-3), 253-263. DOI 10.1007/s10661-007-0117-1

Marcovecchio J E, Botte S E, Freije R H (2007) Heavy metals, major metals, trace elements. Handbook of water analysis, 2, 275-311.

Milovanovic M (2007) Water quality assessment and determination of pollution sources along the Axios/Vardar River, Southeastern Europe. Desalination, 213(1-3), 159-173. doi.org/10.1016/j.desal.2006.06.022 Mohan SV, Nithila P, Reddy SJ (1996) Estimation of heavy metal in drinking water and development of heavy metal pollution index. Journal of Environmental Science \& Health Part A, 31(2), 283-289

Momodu M A, Anyakora C A (2010) Heavy metal contamination of ground water: The Surulere case study. Res J Environ Earth Sci, 2(1), 39-43. 
Nurnberg H W (1982) Voltammetric trace analysis in ecological chemistry of toxic metals. Pure and Applied Chemistry, 54(4), 853-878.

Pandey J, Shubhashish K, Pandey R (2009) Metal contamination of Ganga River (India) as influenced by atmospheric deposition. Bulletin of environmental contamination and toxicology, 83(2), 204-209. DOI $10.1007 /$ s00128-009-9744-2

Panseriya H Z, Gosai H B, Sankhwal A O, Sachaniya B K, Gavali D J, Dave B P (2020) Distribution, speciation and risk assessment of heavy metals: geochemical exploration of Gulf of Kachchh, Gujarat, India. Environ Earth Sci, 79, 1-10. 3. doi.org/10.1007/s12665-020-08972-x

Prasad B, Bose J (2001) Evaluation of the heavy metal pollution index for surface and spring water near a limestone mining area of the lower Himalayas. Environmental Geology, 41(1-2), 183-188.

Prasad B, Sangita K (2008) Heavy metal pollution index of ground water of an abandoned open cast mine filled with fly ash: a case study. Mine water and the environment, 27(4), 265-267. DOI 10.1007/s10230-008-0050-8

Prasanna M V, Nagarajan R, Chidambaram S, Elayaraja A (2012) Assessment of metals distribution and microbial contamination at selected Lake waters in and around Miri city, East Malaysia. Bulletin of environmental contamination and toxicology, 89(3), 507-511. DOI 10.1007/s00128-012-0698-4

Protano C, Zinna L, Giampaoli S, Spica V R, Chiavarini S, Vitali M (2014) Heavy metal pollution and potential ecological risks in rivers: a case study from southern Italy. Bulletin of environmental contamination and toxicology, 92(1), 75-80. DOI 10.1007/s00128-013-1150-0

Reiners W A, Marks R H, Vitousek P M (1975) Heavy metals in subalpine and alpine soils of New Hampshire. Oikos, 264-275.

Selvam S, Venkatramanan S, Singaraja C (2015) A GIS-based assessment of water quality pollution indices for heavy metal contamination in Tuticorin Corporation, Tamilnadu, India. Arabian Journal of Geosciences, 8(12), 10611-10623. DOI 10.1007/s12517-015-1968-3.

Sheykhi V, Moore F (2012) Geochemical characterization of Kor River water quality, Fars Province, Southwest Iran. Water Qual Expo Health 4:25-38

Singaraja C, Chidambaram S, Srinivasamoorthy K, Anandhan P, Selvam S (2015) A study on assessment of credible sources of heavy metal pollution vulnerability in groundwater of Thoothukudi districts, Tamilnadu, India. Water Quality, Exposure and Health, 7(4), 459-467. DOI 10.1007/s12403-015-0162-x

Singh A K, Raj B, Tiwari A K, Mahato M K (2013) Evaluation of hydrogeochemical processes and groundwater quality in the Jhansi district of Bundelkhand region, India. Environ Earth Sci 70(3):1225-1247

Singh G, Kamal R K (2017) Heavy metal contamination and its indexing approach for groundwater of Goa mining region, India. Applied Water Science, 7(3), 1479-1485. DOI 10.1007/s13201-016-0430-3.

Tamasi G, Cini R (2004) Heavy metals in drinking waters from Mount Amiata (Tuscany, Italy). Possible risks from arsenic for public health in the Province of Siena. Science of the Total Environment, 327(1-3), 41-51. 
Tiwari A K, De Maio M, Singh P K, Mahato M K (2015) Evaluation of surface water quality by using GIS and a heavy metal pollution index (HPI) model in a coal mining area, India. Bulletin of environmental contamination and toxicology, 95(3), 304-310. DOI 10.1007/s00128-015-1558-9

Tiwari A K, Singh P K, Singh A K, De Maio M (2016) Estimation of heavy metal contamination in groundwater and development of a heavy metal pollution index by using GIS technique. Bulletin of environmental contamination and toxicology, 96(4), 508-515. DOI 10.1007/s00128-016-1750-6.

Vaiphei and Kurakalva, 2021. Hydrochemical characteristics and nitrate health risk assessment of groundwater through seasonal variations from an intensive agricultural region of upper Krishna River basin, Telangana, India. Ecotox. Environ. Safe. Volume: 213, 2021. doi.org/10.1016/j.ecoenv.2021.112073

Vaiphei S P, Kurakalva R M, Sahadevan D K (2020) Water quality index and GIS-based technique for assessment of groundwater quality in Wanaparthy watershed, Telangana, India. Environ Sci Pollut Res 27(36), 45041-45062, doi.org/10.1007/s11356-020-10345-7

Vinodhini R, Narayanan M (2008) Bioaccumulation of heavy metals in organs of fresh water fish Cyprinus carpio (Common carp). International Journal of Environmental Science \& Technology, 5(2), 179-182.

Voudouris K, Panagopoulos A, Koumantakis J (2000) Multivariate statistical analysis in the assessment of hydrochemistry of the northern Korinthia prefecture alluvial aquifer system (Peloponnese, Greece). Natural Resources Research, 9(2), 135-146.

White D E (1957) Magmatic, connate, and metamorphic waters. Geological Society of America Bulletin, 68(12), 1659-1682.

WHO 2011 Guidelines for drinking-water quality. WHO chronicle, 38(4), 104-8.

Wu H, Xu C, Wang J, Xiang Y, Ren M, Qie H, Lin A (2021) Health risk assessment based on source identification of heavy metals: A case study of Beiyun River, China. Ecotox Environ Safe, 213, 112046. doi.org/10.1016/j.ecoenv.2021.112046

Xie D, Chen C, Li C, Wang Q (2021) Influence of Cd on atrazine degradation and the formation of three primary metabolites in water under the combined pollution. Environmental Science and Pollution Research, 28(13), 16081-16091. doi.org/10.1007/s11356-020-11819-4

Yankey R K, Fianko J R, Osae S, Ahialey E K, Duncan A E, Essuman D K, Bentum J K (2013) Evaluation of heavy metal pollution index of groundwater in the Tarkwa mining area, Ghana. Elixir Pollution, 54, 12663-12667.

Zakhem B A, Hafez R (2015) Heavy metal pollution index for groundwater quality assessment in Damascus Oasis, Syria. Environmental earth sciences, 73(10), 6591-6600. DOI 10.1007/s12665-014-3882-5

Zarazua G, Ávila-Pérez P, Tejeda S, Barcelo-Quintal I, Martínez T (2006) Analysis of total and dissolved heavy metals in surface water of a Mexican polluted river by total reflection X-ray fluorescence spectrometry. Spectrochimica Acta Part B: Atomic Spectroscopy, 61(10-11), 1180-1184. doi.org/10.1016/j.sab.2006.06.010 
Zhang X Y, Tang L S, Zhang G, Wu HD (2009) Heavy metal contamination in a typical mining town of a minority and mountain area, South China. Bulletin of environmental contamination and toxicology, 82(1), 31.

\section{Tables}

Table 1. Statistical summary of water quality data and comparison with WHO (2011) drinking water guidelines

\begin{tabular}{|c|c|c|c|c|c|c|c|}
\hline Parameters & Min & Max & Ave & Median & SD & $\begin{array}{r}\text { Desire limit } \\
\text { (WHO 2011) }\end{array}$ & $\begin{array}{l}\text { No. of samples above } \\
\text { desire limit }\end{array}$ \\
\hline \multicolumn{8}{|c|}{ Chemical Parameters } \\
\hline Temp ${ }^{0} \mathrm{C}$ & 29 & 30 & 29.64 & 29.7 & 0.282 & --- & --- \\
\hline $\mathrm{pH}$ & 7.28 & 8.43 & 7.876 & 7.875 & 0.256 & $7-8.5$ & Nil \\
\hline $\begin{array}{l}\mathrm{EC} \\
\mu \mathrm{S} / \mathrm{cm}\end{array}$ & 640 & 5890 & 1757.93 & 1540 & 965.48 & $750-1500$ & 11 \\
\hline $\begin{array}{l}\text { TDS } \\
\mathrm{mg} / \mathrm{l}\end{array}$ & 409.6 & 3769.6 & 1125.07 & 985.6 & 617.91 & $500-1000$ & 47 \\
\hline $\begin{array}{l}\mathrm{TH} \\
\mathrm{mg} / \mathrm{l}\end{array}$ & 58.5 & 1480.5 & 526.57 & 474.75 & 303.03 & $300-500$ & 27 \\
\hline $\begin{array}{l}\mathrm{TA} \\
\mathrm{mg} / \mathrm{l}\end{array}$ & 60 & 580 & 251.55 & 230 & 107.29 & --- & Nil \\
\hline \multicolumn{8}{|c|}{ Heavy/ Toxic Elements } \\
\hline As $\quad \mu g / L$ & 0.308 & 38.38 & 8.809 & 6.654 & 7.594 & 10 & 13 \\
\hline $\mathrm{Ba} \quad \mu \mathrm{g} / \mathrm{L}$ & 0.033 & 26.71 & 9.487 & 8.4 & 6.839 & 700 & Nil \\
\hline $\mathrm{Cd} \quad \mu \mathrm{g} / \mathrm{L}$ & 0.277 & 0.544 & 0.3245 & 0.314 & 0.045 & 3 & Nil \\
\hline $\begin{array}{l}\mathrm{Cr} \\
\mu \mathrm{g} / \mathrm{L}\end{array}$ & 0.123 & 2.496 & 0.907 & 0.818 & 0.519 & 50 & Nil \\
\hline $\begin{array}{l}\mathrm{Hg} \\
\mu \mathrm{g} / \mathrm{L}\end{array}$ & 0.412 & 8.988 & 4.287 & 4.681 & 2.783 & 6 & 3 \\
\hline $\begin{array}{l}\mathrm{Ni} \\
\mu \mathrm{g} / \mathrm{L}\end{array}$ & 0.012 & 0.865 & 0.37025 & 0.388 & 0.186 & 70 & Nil \\
\hline $\mathrm{Zn} \quad \mu \mathrm{g} / \mathrm{L}$ & 11.69 & 130.2 & 27.047 & 25.28 & 16.061 & 3000 & Nil \\
\hline
\end{tabular}

Table 2. Calculation of HPI for groundwater sample in Wanaparthy watershed 


\begin{tabular}{lllllll}
\hline $\begin{array}{l}\text { Heavy } \\
\text { metals } \\
(\mu \mathrm{g} / \mathrm{L})\end{array}$ & $\begin{array}{l}\text { Mean } \\
\text { concentration } \\
(\mathrm{Mi})\end{array}$ & $\begin{array}{l}\text { Standard } \\
\text { permissible value } \\
(\mathrm{Si})\end{array}$ & $\begin{array}{l}\text { Highest } \\
\text { desirable value } \\
(\mathrm{Li})\end{array}$ & $\begin{array}{l}\text { Unit } \\
\text { Weight } \\
(\text { Wi })\end{array}$ & $\begin{array}{l}\text { Sub } \\
\text { Index } \\
(\mathrm{Qi})\end{array}$ & Wi * Qi \\
\hline $\mathrm{As}$ & 8.809 & 10 & 1.5 & 0.1 & 144.9412 & 14.49412 \\
$\mathrm{Ba}$ & 9.487 & 700 & 50 & 0.001429 & 5.083077 & 0.007264 \\
$\mathrm{Cd}$ & 0.3245 & 3 & 0.5 & 0.333333 & 7.16 & 2.386664 \\
$\mathrm{Cr}$ & 0.907 & 50 & 1 & 0.02 & 0.85102 & 0.01702 \\
$\mathrm{Hg}$ & 4.287 & 6 & 0.25 & 0.166667 & 4.347826 & 0.724639 \\
$\mathrm{Ni}$ & 0.37025 & 70 & 10 & 0.014286 & 16.37833 & 0.233981 \\
$\mathrm{Zn}$ & 27.047 & 3000 & --- & 0.000333 & 0.736667 & 0.000245 \\
\hline
\end{tabular}

$\sum \mathrm{W}_{i}=0.63605 ; \sum \mathrm{W}_{i *} * \mathrm{Q}_{i}=179.4981 ; \mathrm{HPI}=17.86839$

Table 3. HPI classification showing numbers and \% of samples within the HPI range (Kumar et al. 2012)

\begin{tabular}{llcc}
\hline HPI Range & Description of conc. & No. of samples & \% of samples \\
& & & \\
\hline$<19$ & Low & 29 & 50 \\
$19-38$ & Medium & 27 & 46.55 \\
\hline$>38$ & High & 2 & 3.45 \\
\hline & Total & 58 & 100 \\
\hline
\end{tabular}

Table 4. Details on MI classes including numbers and \% of samples in the study area

\begin{tabular}{llccc}
\hline Metal Index & Characteristics base on concentration & Class types & No. of samples & \% of samples \\
& & & & \\
\hline$<0.3$ & Very pure & I & 7 & 12.07 \\
$0.3-1.0$ & Pure & II & 14 & 24.14 \\
$1.01-2.0$ & Slightly affected & III & 33 & 56.90 \\
$2.01-4.0$ & Moderately affected & IV & 3 & 5.17 \\
$4.01-6.0$ & Strongly affected & V & 1 & 1.72 \\
$>6.0$ & Seriously affected & VI & Nil & Nil \\
& & Total & 58 & 100 \\
\hline
\end{tabular}


Table 5. Correlation matrix of physico-chemical parameters and heavy metals of groundwater

\begin{tabular}{|c|c|c|c|c|c|c|c|c|c|c|c|c|c|}
\hline eters & Temp & $\mathrm{pH}$ & $\mathrm{EC}$ & TDS & $\mathrm{TH}$ & Alk & As & $\mathrm{Ba}$ & $\mathrm{Cd}$ & $\mathrm{Cr}$ & $\mathrm{Hg}$ & $\mathrm{Ni}$ & $\mathrm{Zn}$ \\
\hline & $\begin{array}{l}1.00 \\
0.03\end{array}$ & 1.00 & & & & & & & & & & & \\
\hline & -0.07 & -0.59 & 1.00 & & & & & & & & & & \\
\hline & -0.07 & -0.59 & 1.00 & 1.00 & & & & & & & & & \\
\hline & 0.11 & -0.78 & 0.81 & 0.81 & 1.00 & & & & & & & & \\
\hline & 0.03 & 0.44 & -0.07 & -0.07 & -0.40 & 1.00 & & & & & & & \\
\hline & 0.17 & -0.40 & 0.36 & 0.36 & 0.39 & -0.10 & 1.00 & & & & & & \\
\hline & -0.16 & -0.47 & 0.36 & 0.36 & 0.39 & -0.25 & 0.18 & 1.00 & & & & & \\
\hline & -0.11 & 0.01 & -0.07 & -0.07 & -0.07 & -0.01 & -0.06 & 0.10 & 1.00 & & & & \\
\hline & 0.06 & -0.59 & 0.83 & 0.83 & 0.89 & -0.21 & 0.26 & 0.37 & 0.00 & 1.00 & & & \\
\hline & 0.14 & 0.35 & -0.40 & -0.40 & -0.43 & 0.20 & -0.20 & -0.32 & 0.39 & -0.49 & 1.00 & & \\
\hline & 0.09 & 0.24 & -0.05 & -0.05 & -0.22 & 0.29 & -0.11 & -0.29 & -0.02 & -0.12 & 0.11 & 1.00 & \\
\hline & 0.23 & 0.18 & -0.14 & -0.14 & -0.03 & -0.08 & -0.12 & -0.24 & 0.15 & -0.14 & 0.31 & 0.14 & 1.00 \\
\hline
\end{tabular}

Table 6. Details summary of groundwater from all samples in the study area with respect to HPI and MI 


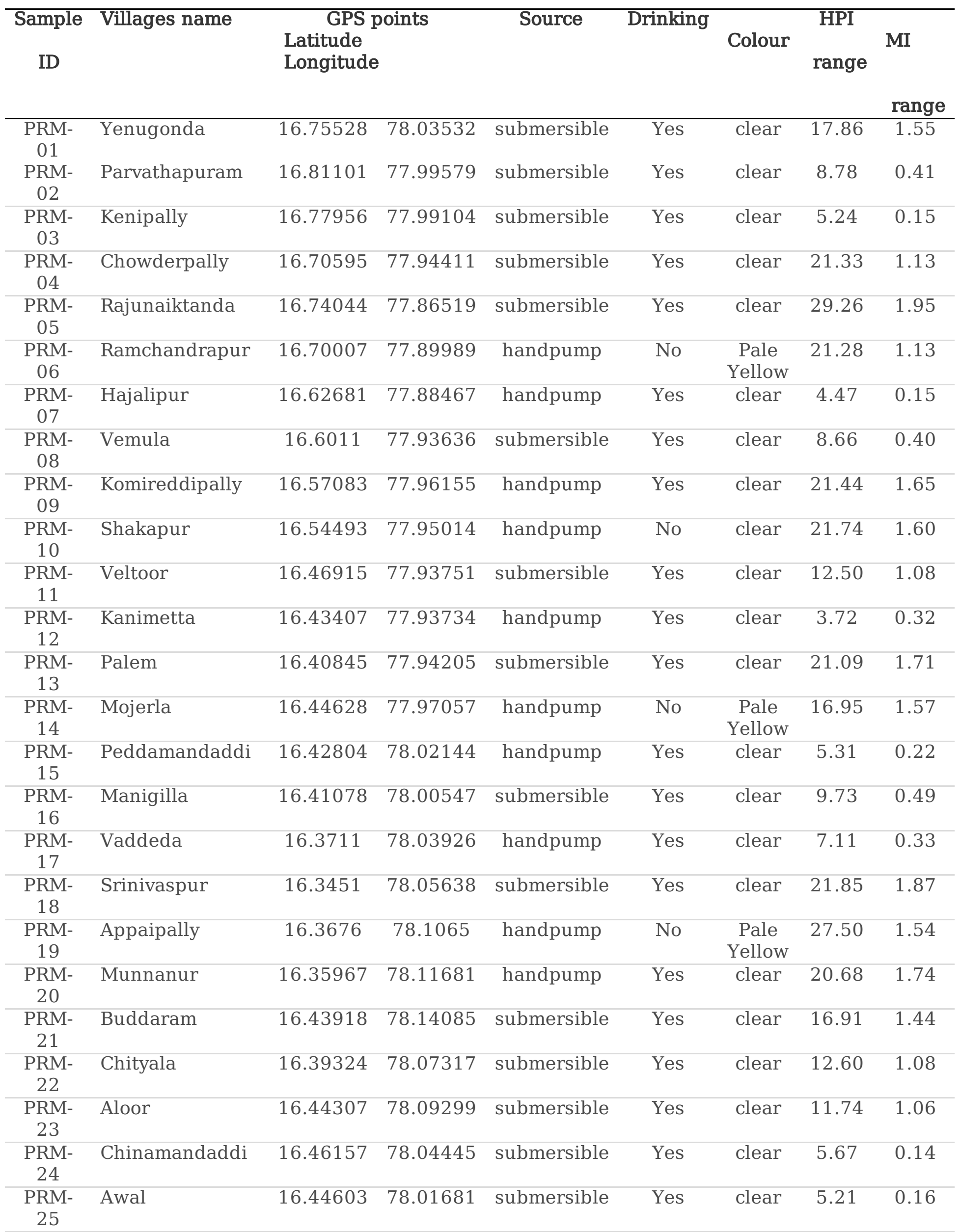




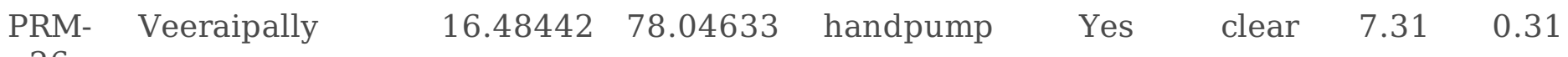
26

PRM- Gatlakhanapur $\quad 16.48215 \quad 77.991 \quad$ handpump $\quad$ No $\quad$ clear $\quad 7.02 \quad 0.60$

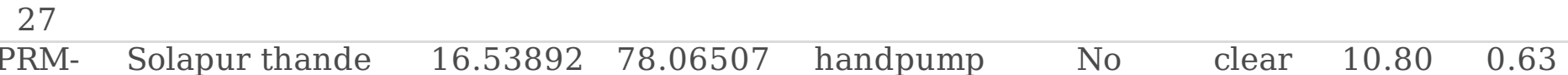

28

$\begin{array}{ccccccccc}\begin{array}{c}\text { PRM- } \\ 29\end{array} & \text { Khillaghanpur } & 16.5728 & 78.04807 & \text { submersible } & \text { Yes } & \text { clear } & 23.39 & 1.51\end{array}$

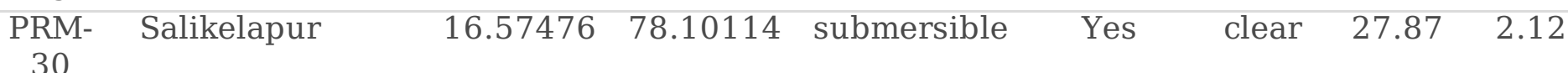

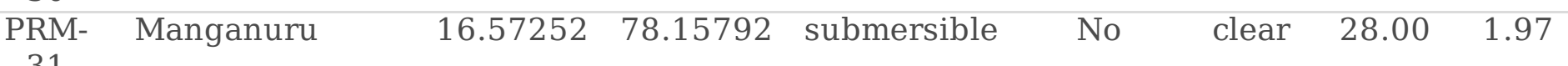

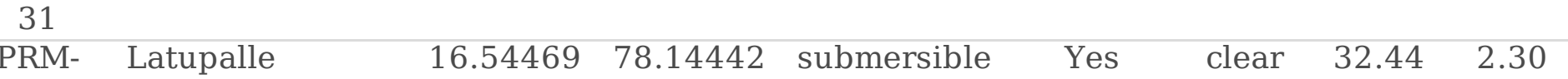

32

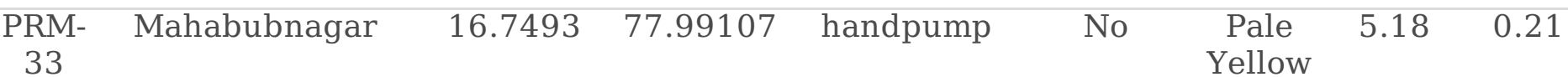

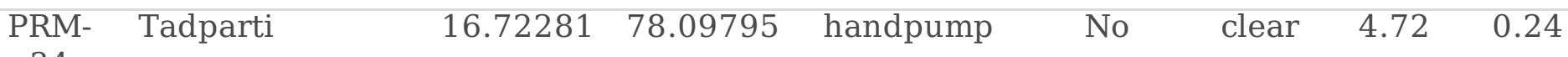

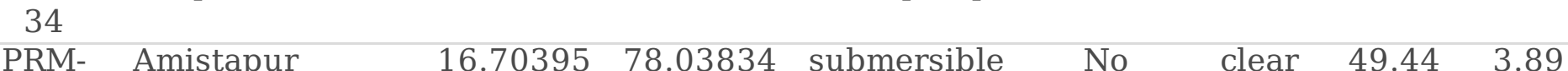

35

PRM- $\quad$ Botlagaddatanda $16.68746 \quad 78.07915$ submersible $\quad$ Yes $\quad$ clear $22.30 \quad 1.54$

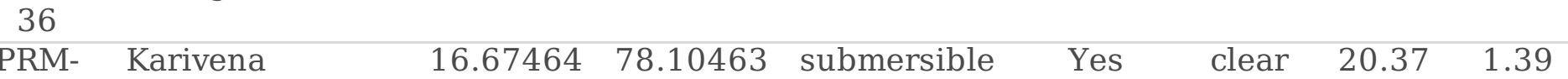

37

PRM- $\quad$ Pullagirithanda $\quad 16.67046 \quad 78.14429$ submersible $\quad$ Yes $\quad$ clear $15.06 \quad 1.05$

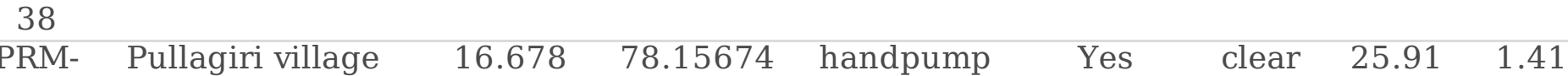

39

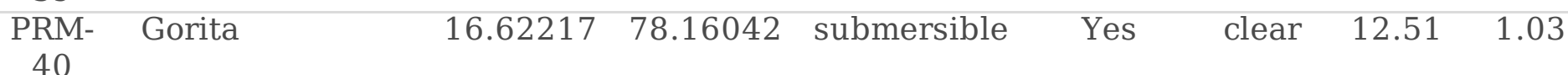

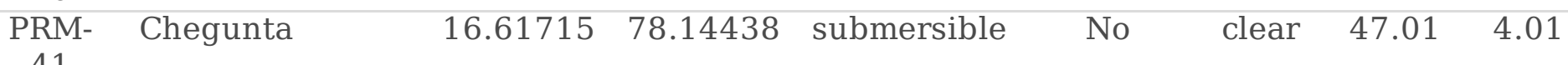

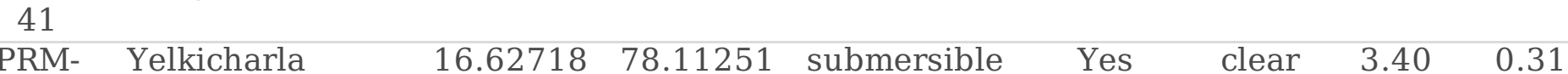

PRM- Yelkicharla $\quad 16.62718 \quad 78.11251$ submersible $\quad$ Yes $\quad$ clear $3.40 \quad 0.31$

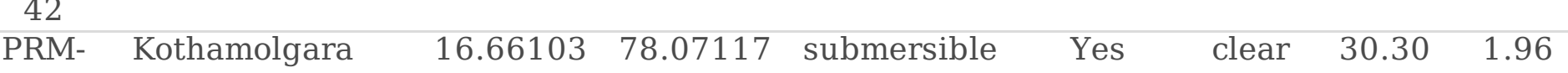

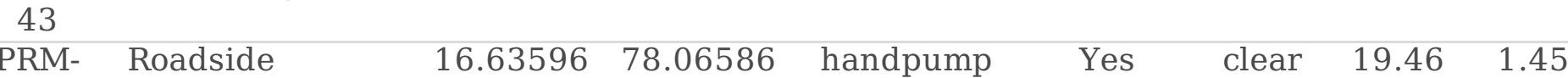

444.9212 submersible Yes

$\begin{array}{lllllllll}\text { PRM- } & \text { Kadur } & 16.67941 & 77.92212 & \text { submersible } & \text { Yes } & \text { clear } & 5.74 & 0.3\end{array}$ 45

\begin{tabular}{llccccccc}
\hline PRM-46 & Oblaipalle & 16.66376 & 77.87949 & submersible & Yes & clear & 23.62 & 1.25 \\
PRM-47 & Gaddeguda & 16.67193 & 77.84102 & submersible & Yes & clear & 7.33 & 0.74 \\
\hline PRM-48 & Janampet & 16.62767 & 77.98649 & submersible & No & clear & 4.84 & 0.37 \\
\hline PRM-49 & Gopalapet & 16.39119 & 78.14268 & submersible & Yes & clear & 14.27 & 1.09 \\
\hline PRM-50 & Chennur & 16.4089 & 78.11878 & handpump & No & clear & 5.37 & 0.46 \\
\hline PRM-51 & Khandoor & 16.54557 & 77.97745 & submersible & Yes & clear & 20.76 & 1.75 \\
\hline PRM-52 & Madanapur & 16.383724 & 77.888394 & handpump & Yes & clear & 17.17 & 1.06 \\
\hline PRM-53 & Dwarakanagar & 16.437511 & 77.879964 & submersible & No & clear & 14.45 & 1.31 \\
\hline PRM-54 & Perur & 16.484203 & 77.876751 & submersible & No & clear & 19.17 & 1.62 \\
\hline PRM-55 & Isrampally & 16.5157 & 77.87473 & handpump & No & clear & 18.36 & 1.29 \\
\hline PRM-56 & Ponnakal & 16.56661 & 77.93799 & submersible & Yes & clear & 19.10 & 1.59 \\
\hline PRM-57 & Jeenugurala & 16.582491 & 77.875398 & handpump & No & clear & 22.58 & 1.94 \\
\hline PRM-58 & Alipur & 16.70156 & 77.9847 & submersible & No & clear & 8.16 & 0.70 \\
\hline
\end{tabular}


Figures
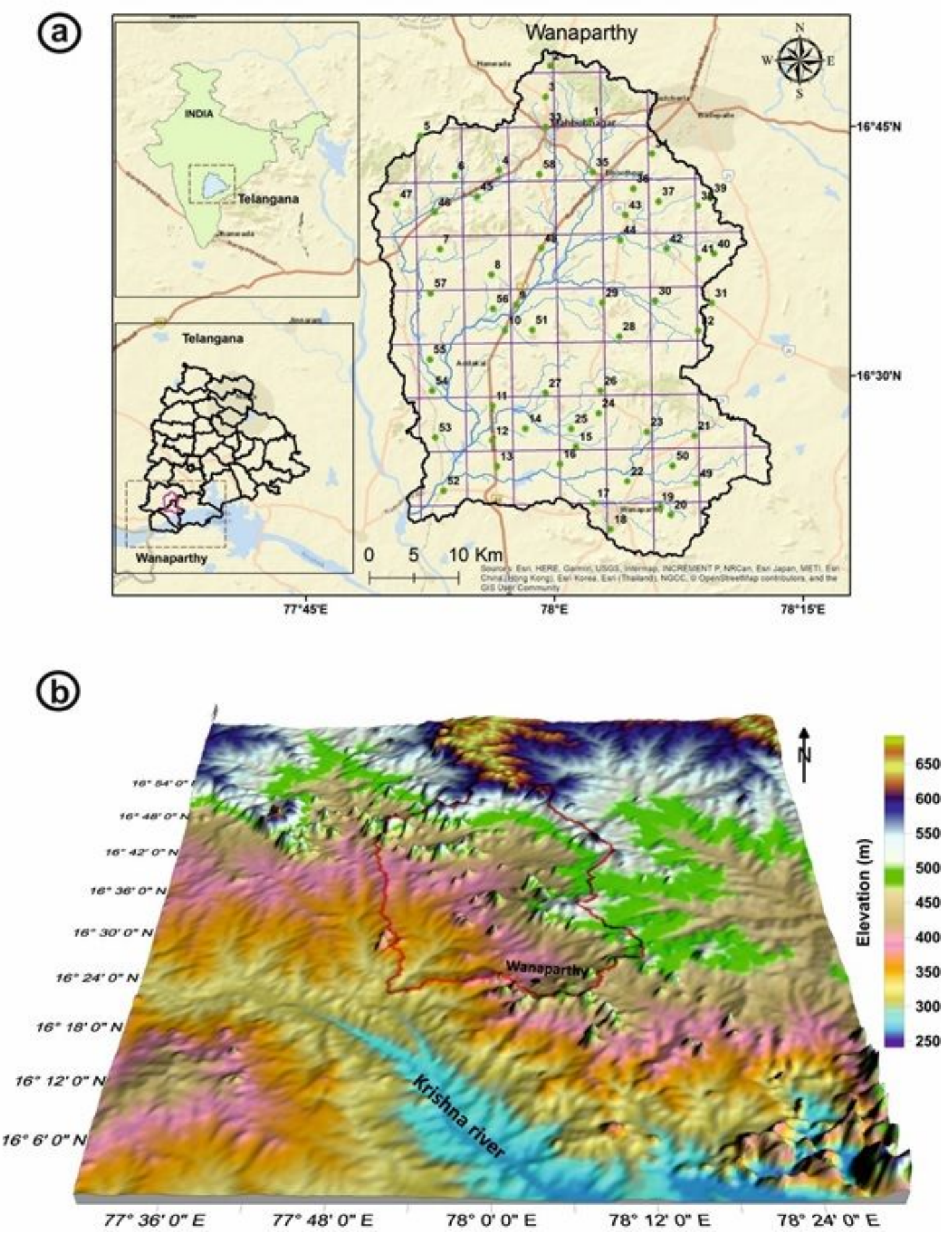

Figure 1

a) Location map along with samples point and b)3D view Wanaparthy watershed 


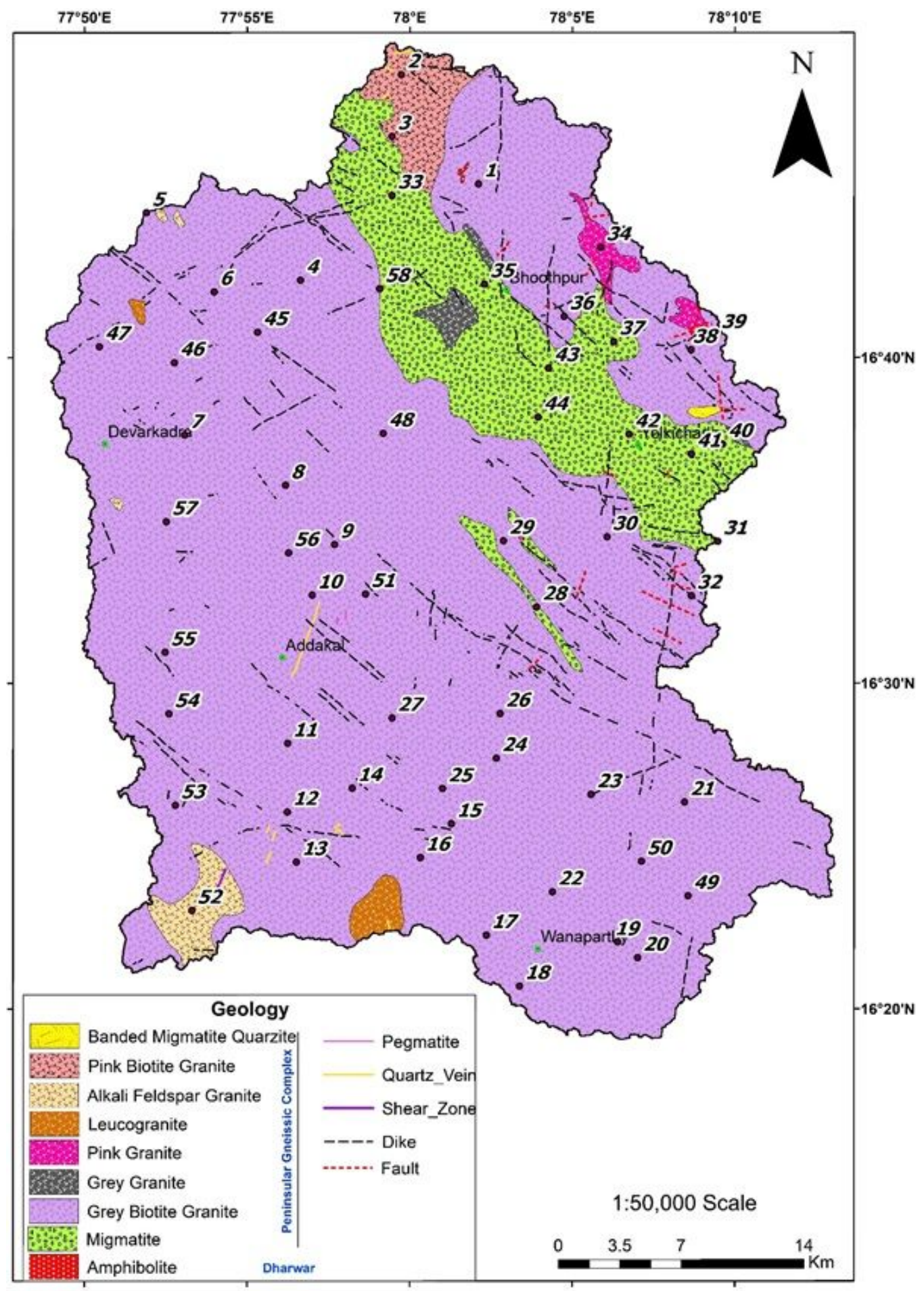

Figure 2

Geological map of Wanaparthy watershed 

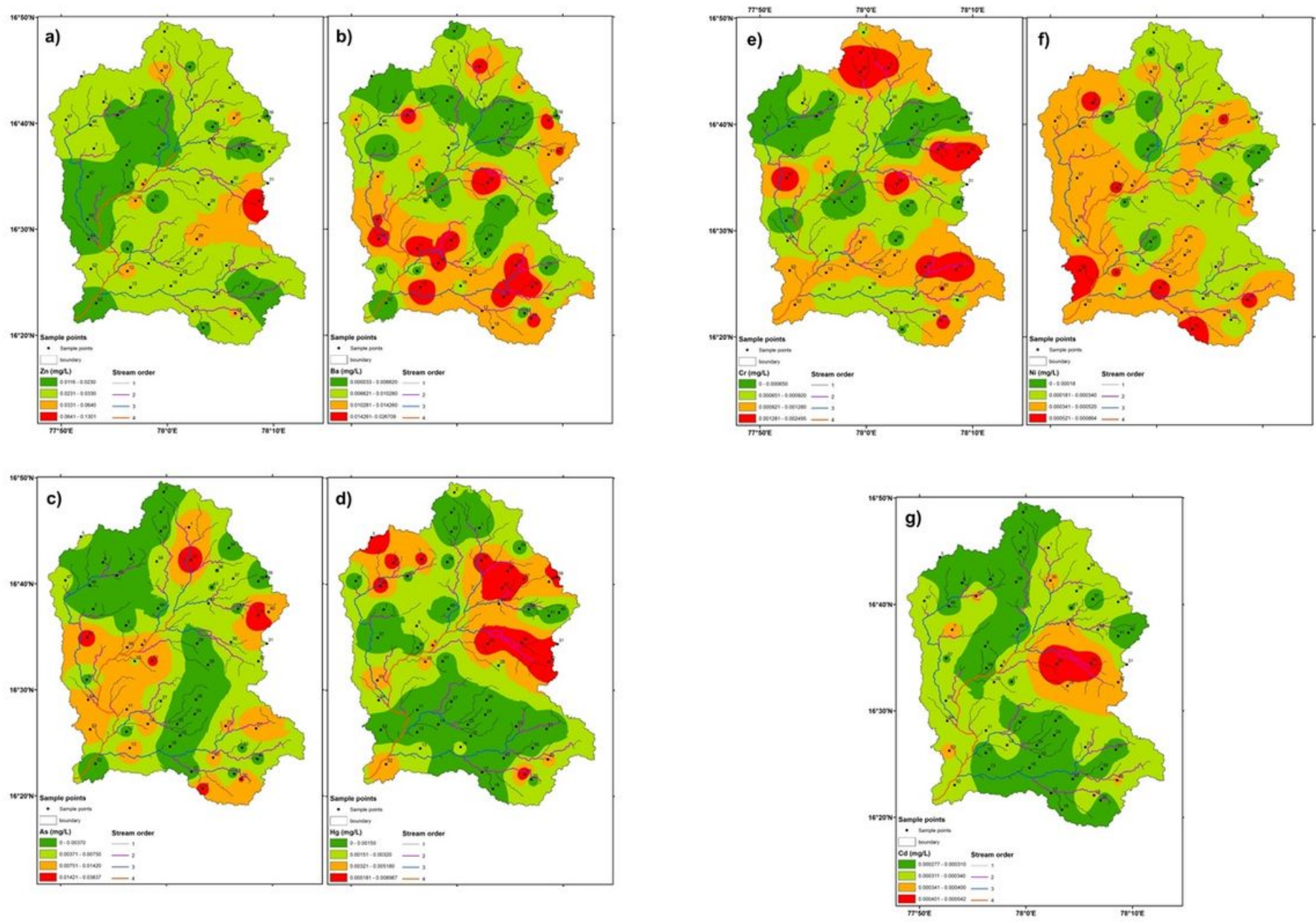

Figure 3

a-g). Spatial distribution map of heavy metals ( $\mathrm{Zn}, \mathrm{Ba}, \mathrm{As}, \mathrm{Hg}, \mathrm{Cr}, \mathrm{Ni}$ and $\mathrm{Cd}$ ) in groundwater.

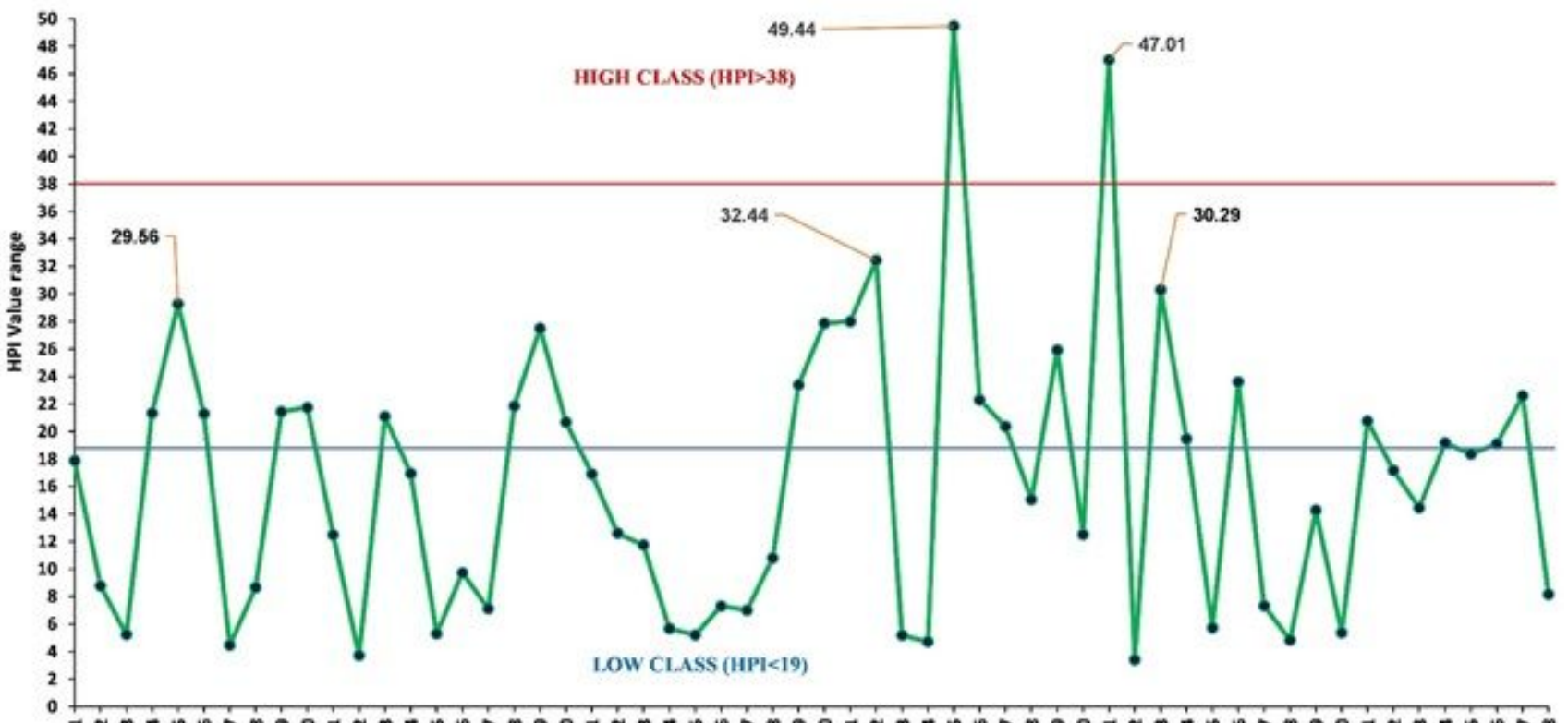


Figure 4

Classification of groundwater based on HPI value

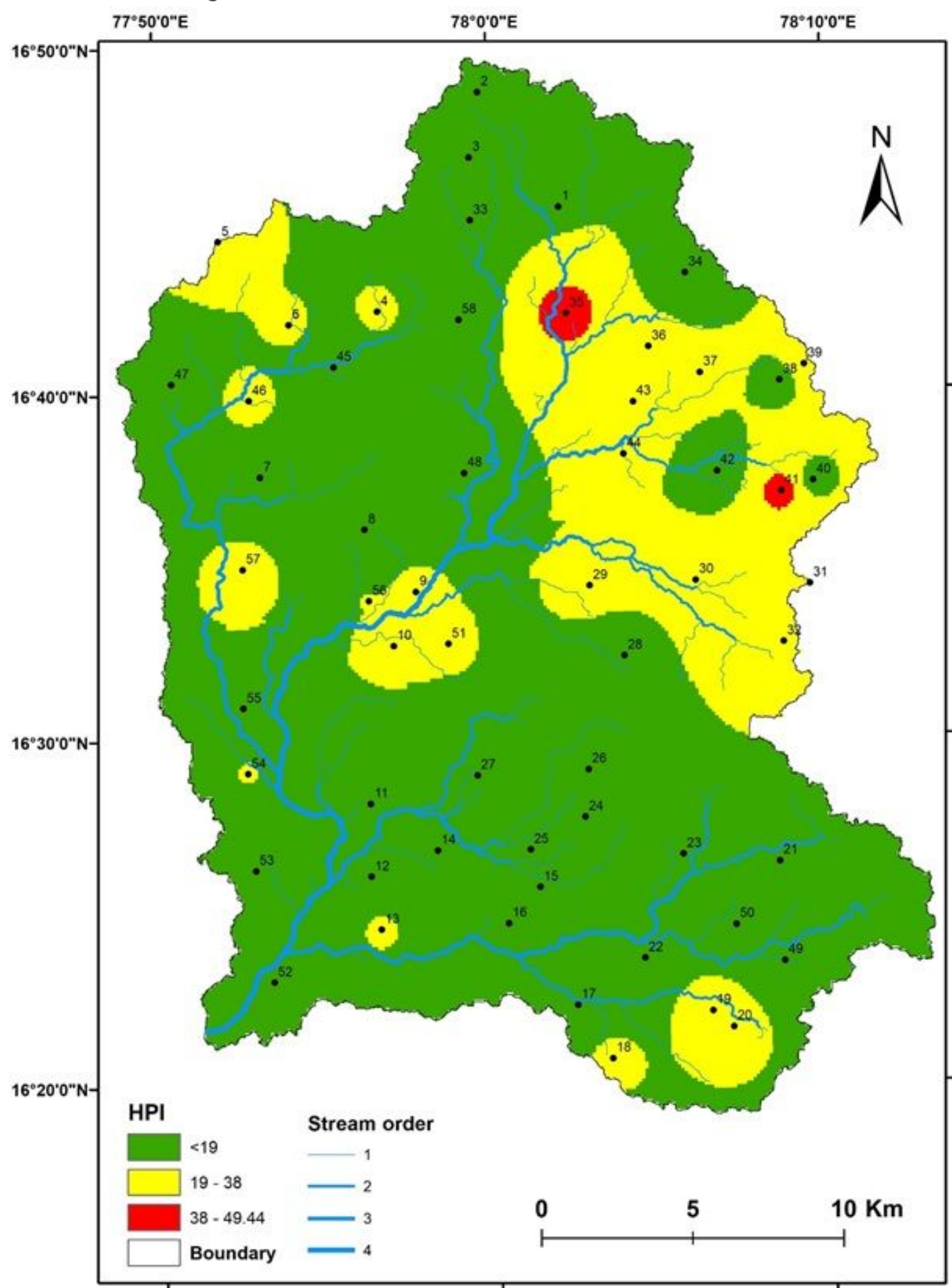

Figure 5

Spatial distribution map of HPI in groundwater of the study area. 


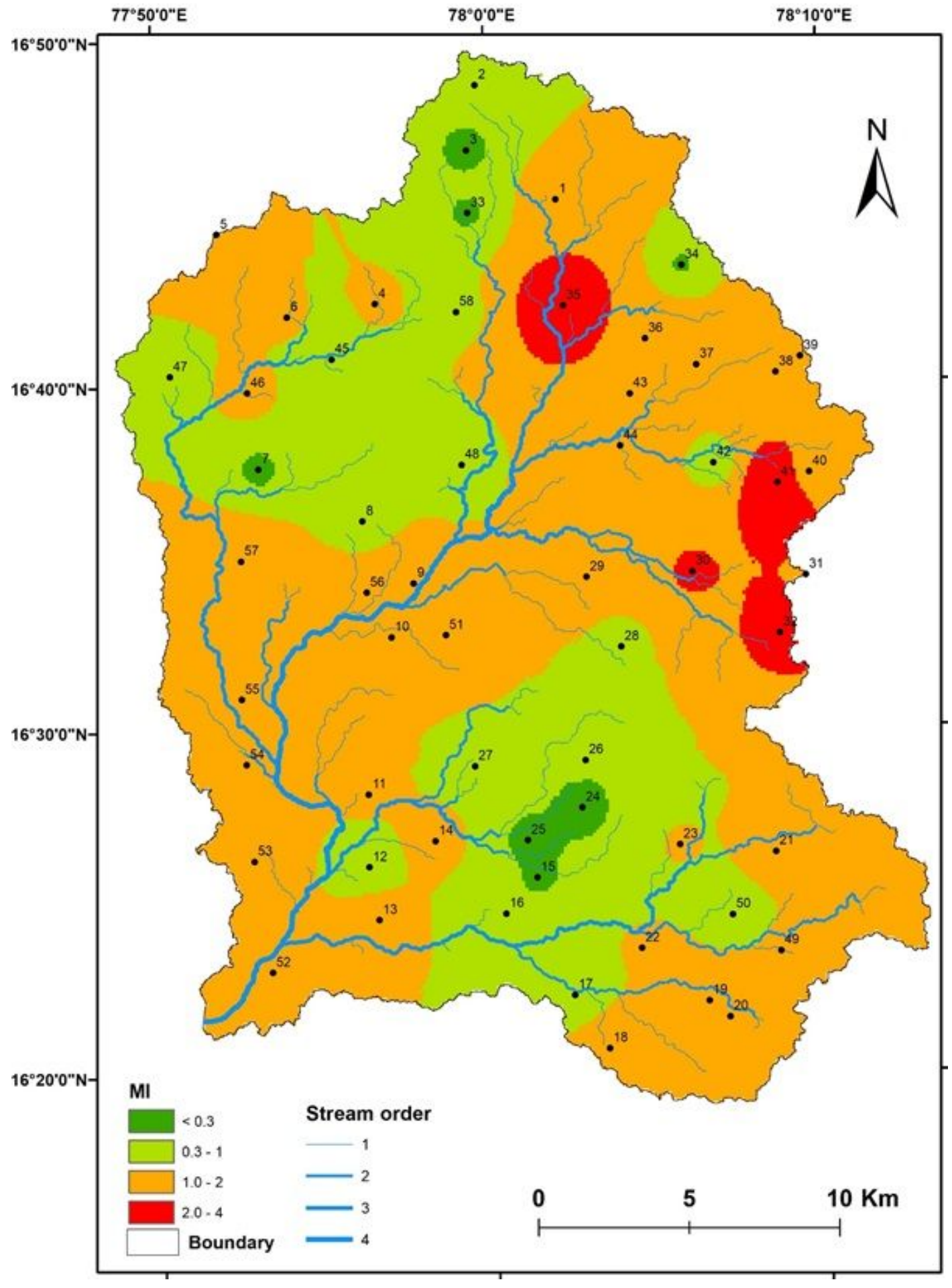

Figure 6

Spatial distribution map of Ml in groundwater of the study area.

\section{Supplementary Files}

This is a list of supplementary files associated with this preprint. Click to download.

- Revisedsuppl.materials.docx 